\title{
"It's the Choices You Make That Get You There": Decision-Making Pathways of Childfree Women
}

\author{
Braelin Settle, MA \\ Krista Brumley, $\mathrm{PhD} *$ \\ Wayne State University
}

* Please address correspondence to Dr. Krista Brumley, Department of Sociology, 2265 Faculty Administration Building, 656 W. Kirby, Detroit, MI 48202. E-mail: kbrumley@wayne.edu.

\begin{abstract}
Using qualitative in-depth interviews with U.S. women, we examined how and why women make the decision to remain childfree. First, we show how women's decision-making pathways were the result of complex factors. Second, we illustrate why the women chose to be childfree, highlighting the benefits of being childfree, the costs of motherhood, and the constraints women felt they faced. Although an exploratory study, our interviews suggest diversity in how women make the decision to be childfree, partly shaped by age, relationship status, and race. Yet our analysis of why women chose to remain childfree did not reveal patterns by their individual characteristics. The women were consistent in the belief that motherhood would disrupt their lifestyle and they would risk not living up to societal expectations of a "good" mother. We argue this shows the power of the social construction of motherhood.
\end{abstract}

Keywords: childfree, gender, motherhood, pronatalism, reproduction

Sociopolitical and cultural forces shape women's decision-making pathways regarding having and rearing children. Macro-level changes like reproductive advancements, the women's rights movement, and increased workforce participation have opened new opportunities for women, influencing their choices about when and if to become mothers (Bartlett, 1995; Blackstone \& Dyer Stewart, 2012; Clark, 2012; Gerson, 1985; Gillespie, 2003; Ireland, 1993). The normative model of men as breadwinners and women as caregivers has declined as more women enter the paid labor market and stay after having children (Avellar \& Smock, 2003; Jacobs \& Gerson, 2004). In fact, 71\% of women with children younger than 18 are employed outside the home (U.S. Bureau of Labor Statistics, 2013). Shifting ideas about women's roles at work and in the family mean more women may choose to remain childfree. In 2008, about $18 \%$ of women age 40-44 had never had a child, almost double the rate than when the U.S. first measured childlessness in 1976 . This trend is rising among women age $25-29$, from $31 \%$ in 
1976 to about 46\% in 2008 (U.S. Department of Commerce, 2011). The data do not differentiate between women who cannot have children versus those who choose not to mother, but declining infertility rates suggest that more women choose to remain childfree (Blackstone \& Dyer Stewart, 2012; Clark, 2012; Somers, 1993).

The purpose of this article is to explore how and why women decide to be childfree. Using data from 20 in-depth interviews with heterosexual, childfree women in the Detroit metro area, we analyzed their pathways and reasons to remain childfree. First, we show how the women's decision-making followed two distinct pathways: Some women made an active and certain decision to be childfree, whereas other women were passive and framed by ambivalence toward motherhood or acceptance of the childfree life. Second, women explained their decision by reflecting on the benefits of being childfree, the costs of motherhood, and personal and societal constraints, suggesting they were hesitant to profoundly change their lives by giving up freedom or taking on emotional and financial risks of motherhood. By examining the micro-processes of women's decision-making, our exploratory study suggests race, age, and relationship status partly shape the women's pathways to childfreedom. However, the reasons the women identified as to why they chose to remain childfree did not differ by their individual characteristics. Instead, their interpretations of motherhood were similar, reflecting the powerful message on what is a "good" mother.

\section{The Social Construction of Motherhood}

Motherhood is socially constructed through interactions and relationships within sociopolitical and cultural contexts (Arendell, 2000; Ridgeway \& Correll, 2004). It is dynamic in its reflection of the prevailing gendered belief system, revealing how motherhood is created and recreated over time (Bartlett, 1995; Gillespie, 2000; Kelly, 2009; Nakano Glenn, Chang, \& Forcey, 1994). In a pronatalist culture, the expectation for women to have children is so strong that motherhood appears as the only normal path, making it difficult for women to be childfree (Brown \& Ferree, 2005; DeLyser, 2011; McQuillan, Greil, Shreffler, \& Tichenor, 2008; Mezey, 2008; Vesper, 2008). Russo (1976) calls this societal pressure "mandatory motherhood." Whereas mothers are celebrated, women who are not mothers are viewed as unfulfilled (Morell, 2000).

The specific ideals associated with mandatory motherhood are not universal and differ by race, class, and sexuality. Societal expectations encourage white, heterosexual, middle class, and college-educated women to fulfill the idealized model of motherhood. Conversely, policies and practices have denied women of color and poor and working class women the ability to preserve family life, excluding them from the so-called "cult of domesticity" (Nakano Glenn et al. 1994). Societal expectations assume lesbian women will not become mothers, so when they do their ability to be "good" mothers is questioned because they challenge heteronormative views on family life (Mezey, 2008). Societal views also portray teenage mothers, waitress moms, and welfare queens as unfit, undereducated, and a "significant problem," particularly for women of color (Parker West, 2002, p. 14). Even deviations from the "ideal" family size of two 
children prompt critique, primarily for lower-income women; affluent women are rarely questioned in the same way. In short, for women who fit the desirable model, motherhood should be central to their adult identity and position in society (Gillespie, 2003; Ireland, 1993; Letherby, 2002; Nakano Glenn et al., 1994). Women who do not fit the "ideal" mother model experience vilification, stereotyping, and critique.

While the ideal of mandatory motherhood is not the same for all women, overarching societal pressure suggests all women should at least want to mother. Thus, women's choice to defy motherhood comes with the burden of not fulfilling their expected role as women, disrupting traditional notions of family. The scholarship on childfree women illustrates complexity surrounding women's choices and challenges. Some women "drift into" being childfree, rather than making the conscious decision, and never revisit the issue (Bartlett, 1994; Ireland, 1993; McAllister \& Clarke, 1998). Other women are ambivalent toward motherhood or simply know at an early life stage that they do not want children (Callan, 1986; Gillespie, 2003; Kelly, 2009; Lisle, 1999; McAllister \& Clarke, 1998).

Micro-level factors influencing why women choose to be childfree add another layer of complexity (Table 1). Research demonstrates that some women's explanations for choosing childfreedom include obstacles to marital happiness (Callan, 1986) and advantages linked to a childfree lifestyle like higher education, a career, or other adult freedoms (Gillespie, 2000; Kelly, 2009; McAllister \& Clarke, 1998; McEvoy, DeVellis, Strudler, \& Acker, 1984; Morell, 1994). Women may want adventure or personal development, act on their reproductive choice, lack a pull toward motherhood, or reflect on their childhood (Gerson, 1985; Lisle, 1999; Mezey, 2008; Morell, 2000). Economics may influence the choice to be childfree as women compare the costs of raising children to socially prescribed benefits (Gerson, 1985; Gillespie, 2003; Ireland, 1993; Morell, 2000). Rather than a simplistic negation of motherhood, the decision to be childfree results from many intricately woven factors.

Table 1

Reasons for Remaining Childfree

\begin{tabular}{|c|c|c|}
\hline Benefits of Childfreedom & $\begin{array}{c}\text { Costs of } \\
\text { Childbearing }\end{array}$ & Constraints \\
\hline $\begin{array}{l}\text { Freedom of lifestyle } \\
\text { Autonomy/independence } \\
\text { Self-development } \\
\text { Greater financial position } \\
\text { Travel } \\
\text { More time with partner and } \\
\text { others }\end{array}$ & $\begin{array}{l}\text { Children as disruptive } \\
\text { Loss of independence } \\
\text { Lifelong } \\
\text { responsibility } \\
\text { Financial risk } \\
\text { Unequal marriage } \\
\text { Career vs. children }\end{array}$ & $\begin{array}{l}\text { No longing toward } \\
\text { motherhood } \\
\text { Emotional expectations } \\
\text { Pregnancy as "barbaric" } \\
\text { No partner } \\
\text { Lack of social support } \\
\text { Childhood experiences }\end{array}$ \\
\hline
\end{tabular}


Most research has focused on childfree women who are white, married, college educated, and upper-middle class, with little religious affiliation, and who hold nontraditional gender beliefs (Abma \& Martinez, 2006; Bartlett, 1994; Heaton, Cardell, \& Holland, 1999; Kelly, 2009; McAllister \& Clarke, 1998; McEvoy et al., 1984; Somers, 1993). Few studies explore the experiences of women of color, unmarried women, or lower-income women (Clark, 2012). Further, most research tends to compare childfree women to those who have children (Callan, 1986; Feldman, 1981; Letherby, 2002; Veevers, 1973), reifying childfree women as deviant and homogenizing their experiences. If we base motherhood or the decision to be childfree only on the experiences of white, middle-class women, we may miss important differences in women's experiences.

This article contributes to the literature in three ways. First, the research is timely, given the increasing number of childfree women. Our study updates the research on childfree women, building on the few more recent studies (Blackstone \& Dyer Stewart, 2012; Clark, 2012; DeLyser, 2011; Tomczak, 2012). Second, the exploratory qualitative study examines the complexity of the decision to remain childfree. Our study shows women follow distinct pathways to be childfree, highlighting how women do not decide in the same way or at the same life stage as one another (Blackstone \& Dyer Stewart, 2012). Third, our findings suggest that research should broaden its focus to examine more closely how race, class, and sexuality shape women's choice to be childfree (Clarke 2012; Hill Collins, 1997; Lisle 1999; Nakano Glenn et al., 1994).

\section{Methods}

This article is based on an exploratory qualitative study of 20 in-depth interviews with childfree women. The literature has defined childfree as "women of childbearing age who are fertile and state that they do not wish to have children, women of childbearing age who have chosen sterilization, or women past childbearing age who were fertile but chose not to have children" (Kelly, 2009 , p. 157). We based our inclusion criteria solely on the women's articulation that they did not want or had never wanted to bear or raise children. We did not ask women about their fertility status. Thus, it is possible that some women in this study may not have been able to have a child, even though they expressed their choice to be childfree.

Existing research uses many terms to describe childfree women: voluntary childless (Callan, 1983; Heaton et al., 1999; Kelly, 2009; Majumdar, 2004; Morell, 2000; Park, 2002), intentionally childless (Feldman, 1981; Morell, 1994), voluntarily childfree (Koropeckyj-Cox, Romano, \& Moras, 2007), childless by choice (Park, 2005), and childless (McAllister \& Clarke, 1998). We use childfree and childfreedom because childless connotes a loss of something (Bartlett, 1994; Clark, 2012; DeLyser, 2011; Gillespie, 2003; Ireland, 1993; Lisle, 1999; McEvoy et al., 1984; Tomczak, 2012; Vesper, 2008; Vinson, Mollen, \& Smith, 2010). In this study, women focus on what their lives have gained as a result of choosing to be childfree.

The data in this article are part of a larger study to explore women's decision-making processes for choosing childfreedom and their experiences as 
childfree women. In-depth interviews focused on (1) the reasons to be childfree, including circumstances that shaped when and how women made the decision, (2) management strategies related to stigmas associated with women who chose not to become mothers, and (3) experiences as childfree women, focusing on how they believed their life was different than those who had children, as well as when they felt their decision was negatively judged or reaffirmed by family, friends, and acquaintances. This article focuses only on the women's pathways and reasons to remain childfree. The first author conducted all interviews, which took place in coffee shops, restaurants, participants' homes, and one of the author's homes. Two women were interviewed over the telephone but were recorded. Interviews lasted 30 minutes to 2.5 hours, most about one hour. The recorded conversations were transcribed for data analysis. We use pseudonyms to protect the women's identities.

We recruited participants through purposive and snowball sampling strategies. Ten women were in their childbearing years (18-39), and 10 women were near the end of their childbearing years or beyond them $(40+)$. While women may give birth after age 40 , only $18 \%$ of women aged $40-44$ do so. Increased risks for chromosomal abnormalities, loss of pregnancy, and health problems during pregnancy also make childbearing more difficult for women in their 40s (Burd, 2012). We purposively constructed the sample by age because we wanted to compare women's experiences given the distinct sociopolitical context within which younger and older women have lived. The women's ages ranged from 20 to 66 , with an average age of 40. Fourteen women were white, four were African American, one was Hispanic, and one identified as white and Arab. Fourteen women were single, two cohabitated with their partners, and four were married. All women identified as heterosexual. All women worked full-time. The nine professionals included positions like lawyers, educators, IT, and management. The nine semi-professionals were in clerical or low-level administrative positions, and the two non-professionals were restaurant servers. While these demographics are important to understand the women in this study, we only found patterns by race, age, and relationship status.

Table 2

Description of Study Participants

\begin{tabular}{llllll}
\hline Name & Age & Marital Status & Race & Occupation & Pathway \\
\hline Vaughn & 37 & Cohabitating & White & Professional & Active, Certain \\
Anne & 33 & Married & White & Professional & Active, Certain \\
Cecilia & 52 & Single & White & Semi-professional & Active, Certain \\
Julia & 57 & Single & White & Professional & Active, Certain \\
Chloe & 30 & Married & White & Semi-professional & Active, Certain \\
Erica & 48 & Married & White & Professional & Active, Certain \\
Kate & 27 & Single & White & Non-professional & Active, Certain \\
Britney & 23 & Single & White & Non-professional & Active, Certain \\
Jane & 29 & Single & African American & Semi-professional & Active, Drifted \\
Faye & 58 & Single & African American & Semi-professional & Active, Drifted
\end{tabular}




\begin{tabular}{llllll} 
Cassie & 35 & Single & White & Semi-professional & Active, Drifted \\
Lindsey & 31 & Married & White & Professional & Passive, Ambivalent \\
Arizona & 34 & Cohabitating & White & Professional & Passive, Ambivalent \\
Courtney & 20 & Single & White & Semi-professional & Passive, Ambivalent \\
Angie & 42 & Single & Hispanic & Professional & Passive, Accepting \\
Samantha & 49 & Single & African American & Semi-professional & Passive, Accepting \\
Marissa & 53 & Single & White & Professional & Passive, Accepting \\
Sandra & 43 & Single & White & Professional & Passive, Accepting \\
Betty & 66 & Single & African American & Semi-professional & Passive, Accepting \\
Kathy & 49 & Single & White/Arab & Semi-professional & Passive, Accepting \\
\hline
\end{tabular}

We used focused and open coding techniques for data analysis to identify emergent themes for the women's decisions to be childfree (Emerson, Fretz, \& Shaw, 1995). Focused coding centered on questions specifically about the decision-making process (see Appendix). We asked, "Can you tell me about the reasons for your decision to not have children?" and "Can you tell how you came to this decision?" We also asked, "When you think of pregnancy and childbirth, what comes to mind?" and "Have there been moments when you second-guessed the decision or when you thought you made the right decision?" We open coded the transcripts to identify descriptions of the women's decision-making process and reasons for their childfree status embedded elsewhere in the interviews. We looked for narratives that described daily life, future hopes, and careers or hobbies that the women identified as not conducive to motherhood. Emergent themes included active and passive decision-making pathways, freedom of lifestyle, children as disruptive, and motherhood as risk. Similar to Gillespie (1999, p. 47), we defined active deciders as women who "had a strong sense of having chosen childlessness in order to concentrate on opportunities other than motherhood and to avoid the activities motherhood entailed." Passive deciders described their decision as happenstance or just the "way it worked out" (Gillespie, 1999, p. 46).

\section{Decision-Making Pathways of Childfree Women}

This study revealed that the decision to remain childfree was the result of several factors rather than one particular moment in time (Gillespie, 1999; Kelly, 2009). Women made the decision to be childfree through active $(n=11)$ and passive $(n=9)$ pathways. Active decider women were certain they did not want children, many deciding early in their lives, or believing they would be mothers but later changing their minds. Some passive deciders had a desire to have children, but without a partner decided against single motherhood, while others felt no push toward or pull away from having children (Gerson, 1985; Mezey, 2008). Within these pathways, our data suggests the women's age, relationship status, and race had some bearing on their decision.

\section{Active Deciders: "I've Never Really Wanted Kids"}

Of the 11 women who were active deciders, eight were certain and three drifted, then were active. All certain women were white and most were younger. Two women still in their childbearing years were single; the other three were 
partner/married. Of the three older women, only one was married; the two women in their 50s were single. Drifted, then active women were all single; two were African American (ages 29 and 58) and one was white (age 35). That only white women had always been certain they did not want to become mothers suggests an element of white privilege to defy cultural expectations of motherhood. Both women of color thought they would be mothers but changed their minds. Drifted, then active women were also all single, pointing to constraints that led them to actively maintain their childfree status.

When women who were certain discussed their childfree choice, they stressed how they knew they did not want to be mothers. Chloe, a white 30-yearold, had been married for eight years. At 22, she sought sterilization; at 25, her husband attempted to get a vasectomy. Their doctors refused them due to their age. Chloe never felt a desire to have a child:

I've never really wanted kids. It's never been something that I dreamed of, and I don't particularly like the idea of being pregnant. I like kids; I just like them to go home at the end of the day. So it's not something I ever really wanted.

Other certain women echoed Chloe's perception, mentioning benefits that they associated with a childfree life like the desire to travel, financial independence, and the ability to come and go as they pleased. Vaughn, a white 37-year-old, also never felt the pull toward motherhood, stressing it was a lifelong commitment:

I'm really independent and it's scary thinking about having this being dependent on me for the rest of its life. Even after kids grow up and move out you still have that attachment and the worry and the stress ... That's a big responsibility and decision that I don't think a lot of people really think about.

A few women also mentioned childhood experiences that shaped their decision to avoid motherhood. Cecilia, a white 52-year-old, did not have children because she "was not going to take a chance that they were going to turn out to be anything like my mother," whom she described as "controlling, jealous, um, a bitch." Julia, a white 57-year-old, had a brother with a learning disability. She saw her parents' difficult experience raising a child with special needs. When she met her late husband, he had grown children. She believed if his children had been younger, she would not have been in a relationship with him. The complications and responsibility of children, paired with never experiencing a draw to motherhood, framed the women's early and active decision.

In contrast, drifted, then active women believed they would be mothers but later identified factors like financial instability or the immense responsibility required that led them to actively pursue their decision. Jane, a 29-year-old African American, explained:

At one point I wanted children. I thought it was cute, I was like,

“Oh, everybody has a child." Then as I've gotten older I don't want the responsibility. I think it takes a special person to become a parent and I don't think I'm that person.

Similarly, Cassie, white and 35, also thought she would have children, but her idealized version of adulthood was disrupted after college: 
When I was little I felt I wanted kids, when I'm young I assume I'm gonna be married and have kids and everything by the time I'm 26 ... By 26 I was still living with my parents and I was like, "This is completely unrealistic." Then the more I got out on my own it was like, "No way, I'm not doing it."

Both Cassie's and Jane's narratives were suggestive of the societal pressure for women to fulfill their expected role as mothers. Only as adults did women interpret what becoming a mother would entail-emotional and financial commitment - that led them to actively pursue a childfree life. Although much older, Faye too decided not to pursue motherhood because she stressed a childfree life meant "more freedom." At age 40, she intentionally sought sterilization.

Although initially believing they would be mothers, the drifted then active women challenged the assumption that all women should at least want to mother.

Active decider women did not simply negate motherhood but had a strong desire to be independent. Only one woman cited a specific dislike of children; the other women believed their lives were better as they were, associating motherhood with the loss of freedom, a high level of responsibility, and selflessness. Whereas only white women were certain, the two women of color thought they would be mothers, drifting until taking an active decision to be childfree. We cautiously suggest that white women may have more "choice," and perhaps the women of color feel more community pressure to fulfill women's expected motherhood role, yet the costs and constraints associated with motherhood ultimately outweigh any previous desire to mother. That the majority of active decider women were of childbearing age suggests sociopolitical and cultural changes like reproductive advances and women's increased workforce participation gave the women more opportunity to voice their choice to defy motherhood.

\section{Passive Deciders: "It Just Kind of Happened Naturally"}

Of the nine passive deciders, three women were ambivalent and six were accepting. Ambivalent women felt no distinct pull toward motherhood but also made little effort to avoid having children. All were white and still of childbearing age. One woman was single and two were partnered/married. Accepting women felt some draw toward motherhood but chose not to have children. The women were all single and older than 40; four of the six were women of color.

Passive decider women who were accepting of their childfree life talked about how "it just kind of happened naturally." They explained that their childbearing years had come, or were coming, to a close without the "optimal" circumstances for motherhood. They were drawn to motherhood, but were childfree because of constraints like finances, careers, or the lack of a partner. Samantha, a 49-year-old African American, helped rear her nieces and nephews as she watched her sister, who was a young single mother, struggle to raise them. She "promised" herself that she would only have children if she was married. Samantha's experiences with "shared" parenting shaped her decision to not mother alone. Similarly, Kathy, a white/Arab 49-year-old, reflected on her childhood. Her parents divorced while she was young, and she saw the stress of 
single motherhood. Her mother passed away while she was a teenager, and she took care of herself with little financial support:

I want to say it wasn't a choice that I thought about. I think it was more my life circumstances up to a certain point, and then once I got to a certain age and a certain point I knew that it probably wasn't going to happen.

Other accepting women too decided against motherhood because of the lack of a spouse. Angie, 42 and Hispanic, explained "it's just how my life worked out." She had not married, but she had always "thought from the time I was a small child I would not have kids out of wedlock." Likewise, Sandra, a white, single, 43-year-old reflected:

That's a difficult question. I never at any point in my life did I say

I will not have children. However, I think that there are things that

I could have done if just having a child was my sole goal.

Likewise, Marissa, a white 53-year-old, chose not to have children without a partner:

It happened naturally. I never met anybody to have children with. So I didn't choose-I chose not to do it alone. Like a lot of women these days who will adopt if it comes to that because they refuse to be childless even if they don't have a husband. So I did choose to remain childless without a partner.

All the accepting women believed motherhood would become part of their life narratives, but personal constraints, particularly the lack of a partner, led to their childfree lives. The women's relationship status overshadowed their desire to be mothers, confirming how "good" motherhood means having a partner in the journey. That almost all accepting women were of color suggests race may distinctly shape how women decide to be childfree. Unlike their counterparts, who actively decided to defy motherhood because of costs associated with motherhood, these women pointed to constraints that led to their childfree lives.

In contrast, ambivalent women made little effort to have children or to avoid doing so. The women were not undecided or fence-sitters because they were firm in their intention to remain childfree. These passive decider women seemed content with their decision to be childfree. However, because the women were still in their childbearing years, they acknowledged that lives can quickly change and if circumstances, like an unplanned pregnancy, forced them to revisit their decision, they may make a different decision. The ambivalence expressed by the women illustrates how the choice to be childfree is a fluid process. Arizona, a white 34-year-old, said she never felt a strong urge to have children, but would keep a child if she were pregnant. When asked if she was practicing any forms of birth control:

That's why I hesitated with my answer. Like, I don't really plan on having kids and if anything it's just timing, you know, with your menstrual cycle and then not overdoing it right when you think there is ovulation. So I guess if you want to call that birth control. I'm just not trying very hard. So you know that's why I always say I can't say that I've made the decision so concretely, because I'm 
gonna be 34 next month and having an abortion at this time isn't what I'd like to do.

Lindsey, a white 31-year-old, believed her job shaped her decision:

At this point, yes. This is going to sound awful, but honestly, I think a huge part of it is because I teach elementary school. I have seen what they can turn into and my job can be so tiring and so draining I can't imagine coming home and continuing to do that. [I] never had the desire. Lots of women my age that's all they think about. Not me.

Our findings show that the women's decision to be childfree followed two pathways, shaped by age, relationship status, and race. Active decider women focused on the costs of motherhood in their decision-making; passive decider women centered on the constraints. Race mattered in that all women of color thought they would become mothers at some point; two changed their minds during childbearing years, actively maintaining a childfree life, and four accepted their childfree life. Only white women never felt a pull toward motherhood, indicating their certainty at an early age or stating they were ambivalent about their status. They are all single, but active deciders were younger and passive deciders were older. That certain or ambivalent women are white suggests the women may be privileged in defying motherhood; women of color may experience more pressure within their communities and expectations to combine work and family, even if they are judged more harshly by society. That active decider women are younger and passive decider women older could be because younger women may have felt more comfortable making and voicing their decision at an earlier age, while in retrospect, older women felt as though their childfree state was "just how life turned out."

\section{Reasons for Remaining Childfree}

In this study, women believed the costs and constraints of motherhood outweighed the benefits. Women attributed the benefits to enhanced autonomy and the ability to make choices about education, career, or personal development. Women framed children as disruptive, stressing the costs of motherhood like the loss of independence, identity, finances, and career (Lisle, 1999; Morell, 1994); women imagined the "losses" of motherhood but not the rewards, characterizing motherhood as a sacrifice, a duty, and a burden. Women identified constraints like the lack of a partner or the lack of emotions that women presumably embody, an overlooked aspect of the decision-making process to remain childfree, as reasons to be childfree. Unlike the women's decision-making pathways, individual characteristics like race, age, and relationship status did not differentially shape why the women choose to defy motherhood; the consistency in their framing illustrates the power of the social construction of motherhood.

\section{A Childfree Lifestyle: "Having the Option to Do Anything, Anytime"}

Women identified the benefits of childfreedom as freedom of lifestyle and opportunities for self-improvement. Freedom of lifestyle was marked by greater 
financial position, the ability to "get up and go," travel, and to spend time with others. Cassie, a white 35-year-old, explained:

I think having the option to do anything anytime is priceless. Friends with kids can't do that. "Well, let me see if I can get a sitter," "I couldn't get a sitter," "I can't make it, I haven't been out in months, this sucks." If I wanted to go back to school, take on a new career or move, I have that luxury. If I find a good job opportunity out West I can leave; you can't do that when you're a parent.

Similarly, Faye, 58 and African American, echoed the value of having a freer lifestyle:

If I want to go to bed at 6 o'clock, I don't have to worry about nobody. If I want to go out, I can go out. If I wanted to travel I could travel ... I used to go to the gym all the time, leave work, work out for two hours, then come back home. It was more freedom-I made my own decision.

In Cassie's and Faye's comments we hear that freedom means doing what one pleases and the ability to live life for oneself and not for the sake of children. Financial benefits were also an important part of their understanding of the "freedom to do what I want," as Chloe, 30 and white, emphasized: "I don't have to think about [if] junior needs shoes next month or whatever. It's just that I need shoes this month. I want shoes this month."

Freedom of lifestyle entailed dreams of travel. In fact, more than half of the women mentioned traveling. Cassie, 35 and white, explained:

I really want to travel. I want to see stuff I've only seen in books. I'd like to go to Hawaii, but I also want to go to Egypt and Greece and take three months and do something exciting. You don't have those options when you have kids. It's tough enough finding someone to watch my dog for that long-but a kid?

Arizona, 34 and white, believed her lifestyle benefited from not having children: I like to travel a lot, more than just within the United States. I don't want to be the person on an airplane with a screaming child. I don't wanna be in a restaurant with a little kid. I just don't think it fits my lifestyle. I've always kinda felt like it doesn't fit my lifestyle and it's not going to.

Women stressed a childfree life allowed them to travel; children put a damper on this activity, as Britney, 23 and white, reflected:

This is going to sound so dumb, but seriously going to [the amusement park] Cedar Point. When I see people with a stroller, what the hell are you going to do? You can't ride the rides with a stroller, or a baby, or an infant; why are you even going? 
Women also identified opportunities for self-development. Vaughn, a white 37-year-old, explained how childfreedom meant more time for herself: Just learning how to do other things that you might not have time to do like learning to sew, or picking up a hobby_I have a vintage bike that I'd like to learn how to fix up. I enjoy learning new things and experiencing new things.

Marissa, white and 53, argued that a childfree life meant more opportunity for a broader range of interests and experiences, rather than parents who seemed to have a singular focus on their children. She described:

I think I'm a much more-I don't want to say worldly, but I would say more interesting. People that have kids tend to talk about their kids and it's like, they live through their kids. When they're talking about social lives, they're talking about their kids' social lives.

When they're talking about hobbies they're not talking about theirs, they're talking about their kids'.

The women's reflections on the benefits of childfreedom entailed financial freedom, travel, or simply "getting up and going." They discussed the luxuries of free weekends, living in hip, urban locations, and freedom of mobility, which they thought they would have to give up if they were mothers. Women believed motherhood signified they would not be able to cultivate other identities because they perceived it would be their dominant identity. Their positive framing of their childfree life outweighed any perceived benefits of motherhood, suggesting they were aware of the costs of having to live up to these expectations.

\section{Children as Disruptive: "I Never Wanted to Change My Lifestyle"}

When women considered the costs of motherhood, they framed children as disruptive. Women characterized motherhood as "responsibility," "sacrifice," and "putting others first." They associated these expectations of a "good" mother with the loss of independence, an aspect of their lifestyle they valued most. Vaughn, 37 and white, explained motherhood meant: "not being able to do the things that I'd like to do. There's a lot of things I haven't done, and when you have a child you're even more limited to the things you can do."

The women tightly wove their discussion about what they would have to abandon with their understanding of motherhood. Vaughn continued: "[I]t's kind of scary thinking about having this being that was dependent on me pretty much for the rest of its life." She spoke about how even after the children grow up and move out there would still be the "attachment and the worry and the stress, I mean, that's a big responsibility and a big decision that I don't think a lot of people really think about." Similarly, Cecilia, 52 and white, echoed this feeling: "I don't have anyone to take care of but me." The responsibility of having someone dependent on them pointed to a central cost, as Chloe, 30 and white, emphasized: "I am pretty independent. I like being able to go out and do my own thing. I run a lot, and that would be kinda difficult to do that if there's a kid that I have to take with me." 
Women stressed motherhood was a lifelong commitment. Britney, 23 and white, believed she would not be "able to do anything for at least 18 yearsanything-without someone else." Jane, 29 and African American, reflected on her reliance on her parents:

You're a parent forever and I don't think people understand that. I still call my mom and dad and I'm damn near 30. They' re probably like, "Get a grip!" Did you think about this when you signed up? Probably think "Oh she's gone away to college, she bought a house - she can take care of herself," but when I'm sick the first person I call is my mom. I call my dad, "Oh can you do this and can you do that?" And even to this day I think they're like, "She's a lot of work."

The frame of children as disruptive was visible when women linked the loss of independence to balancing work and family. Women characterized motherhood as a "huge responsibility" and "burden" that did not fit women's lives if they were career-oriented. For example, Anne, 33 and white, felt she would not fulfill her career aspirations if she were a mother: "My husband and I live in a loft downtown. We're both really career-focused; we're both in IT so we work a lot of hours, and that would definitely have to change if we did have kids." Similarly, Arizona, 34 and white, felt her career did not easily fit motherhood:

My career, there's not much time off. I teach all year pretty much; it doesn't seem like I have the best career for that. Plus I am in an egalitarian, dual-income, dual-earning household situation. It would hurt if I didn't work as much. And I don't know, I just feel like since I was in school for so long there's so much more that I have to do. And I don't think I will be able to do all that having a child.

Women emphasized children as disruptive when they considered the financial responsibility. Vaughn, 37 and white, felt that she did not make enough money to raise a child: "I don't make a lot of money; I can't imagine being able to support another being on the money I make. I mean, I'm not struggling, but if I did have a kid it would be really difficult for me." Likewise, Marissa, 53 and white, stressed that having children could create financial insecurity: "I was worried about taking on that responsibility and then finding myself in a situation where I'm financially in a tough spot." Children also posed a financial dilemma that spilled into their decisions on work, as Cassie, 35 and white, explained that she had seen women leave their jobs because of the high cost of child care. She argued that women were working just to pay for day care and that it did not "make sense" because that is "not what having a kid is supposed to be about." Cassie's reflection continued as she underscored how her parents sacrificed financially:

I look at my parents: They didn't travel, they didn't do anything. Both my parents had to work-and my mom had stopped working 
then had to go back to put me through college ... I don't want to have to share it with anybody.

The women believed life was difficult enough, let alone having a child, as Kathy, 49 and white/Arab, emphasized, "[I]t's hard enough to keep yourself going, and to bring a child or children into the picture makes it that much more difficult." Their financial assessment in relation to children meant motherhood would place a burden on their current lifestyle.

Women also equated children as disruptive with selfishness. Childfree women face stigma for choosing not to have or rear children for so-called selfish reasons. Women in this study internalized this assumption, revealing tension in their choice to be childfree. They believed in their decision, but signaled they might not have been good mothers. For instance, Cassie cited her parents' financial struggles but also framed her decision as selfish:

I would rather spend my earnings on myself. I'm pretty selfish. It's my money, I work hard for it, I don't want to fork it all over for the benefit of someone else, even if it's my offspring. I would just end up resenting my kid in the long run.

Lindsey, 31 and white, stated:

I'm also super selfish and some of my favorite things in the world you have to give up when you have children. I don't want to give them up yet. And free time, being able to go visit friends for the weekend, or sleep in really late on the weekends. And just having quiet time. I'm "on" all day and when I come home I just wanna sit. I don't want to entertain anymore.

According to Erica, 48 and white, childfreedom meant she maintained her lifestyle: "I never wanted to change my lifestyle 'cause I knew it would change a lot. I think it was very selfish. I just didn't wanna change the way I was living and give up a lot of things."

When women talked about motherhood as a sacrifice or the necessity of selflessness, they reaffirmed expectations of the "ideal" or "good" mother. Their construction of the costs of motherhood meant that a "mother" identity was prioritized over other possible identities like wife, girlfriend, partner, or careeroriented. Motherhood was a significant responsibility that negated their freedom of lifestyle, compromising their independence.

\section{The Emotional Risks of Motherhood: "I Would Have Been the World's Worst Mom"}

Women discussed personal and societal constraints associated with motherhood. Women recognized the emotional risks associated with motherhood. They framed avoiding motherhood as the lack of desire or "biological clock" that women are expected to have. Women voiced concern they would not have the maternal instinct to fulfill motherhood. Some women, like Vaughn, 37 and white, feared they would never develop the "unconditional love and caring": 
I don't have that desire to have them. I don't feel like I need that. A lot of people are like, "Aren't you afraid you're not leaving a piece of you behind and when you die, that's just it-you're done." That doesn't affect me either way.

Anne, 33 and white, concurred:

I don't have any desire to have kids ... I feel like if I did have kids the only reason I would be is so I had someone when I was old [laughs] to take care of me and I really don't feel like that's a good enough reason to have children. And you know, everyone that I know that's having kids is because they want to have kids and they want to reproduce. I just don't have that. I don't have that mother instinct.

The women's sense that they lacked the maternal instinct was common among their explanation to be childfree. They understood that this perceived lack challenged normative prescriptions of women as innately nurturing. Jane, 29 and African American, stated: "Some women say they have this urge to be a mother. I don't have that. Maybe I'm a weirdo. I'm sure society frowns upon me. I don't feel the need. It's not appealing. I don't look at a baby and get goose bumps."

Other women reflected on their characteristics that they believed would preclude them from "good" motherhood. Kathy, 49 and white/Arab, believed that her personality traits would have made her an overbearing mother: "I am actually a very anxious person. So sometimes I sit back and I think about that, I just probably would have been the world's worst mom." Similarly, Julie, 57 and white, also expressed that she had freedom from worry: "You know, not worry about children, not worry that they're safe. That would be an issue for me. I'd be so neurotic and I'd be like, not letting them be independent or free. I'd see being too, I don't know, hovering." In contrast, Marissa, 53 and white, simply did not think she had the patience:

Even though I love little babies and little kids, once they turn 13 I don't want anything to do with them. What do you do now that you've made the commitment as a parent? You can't just say, go to boot camp until you're 18 . Some people who decide to have children, I don't know if they think that far ahead. I see it with other people and it's not fun. I don't know how I would've handled it. Especially now it seems that kids have become a lot more disrespectful.

The women understood that mothers were to find a delicate balance between caring and hovering/impatience. That they felt unsure of their ability to do this demonstrated the pressure associated with being a "good" mother.

A few women discussed how their relationship with their parents shaped their decision to remain childfree. Cecilia, 52 and white, had a tumultuous relationship with her mother: 
I was not going to take a chance that they were going to turn out to be anything like my mother. ... I was always dodging bullets, and I thought, "I am not going to do this to anybody else, oh my god, I can't do it."

Cecilia also had a distant relationship with her father, explaining that he was a functional alcoholic, but she "thought everybody's dad came home from work and went down to the corner bar until mom called to get him, or you were sent to get him." Britney, 23 and white, also had a strained relationship with her parents. She did not want this if she had children:

My parents should have never had kids, so I feel that I shouldn't

have kids because I don't want to be like them. Plus the divorce

rate in my family and in life is so high, and I feel like kids

shouldn't have parents that aren't together.

The women's identification of their personal constraints showed how they had internalized societal expectations of motherhood. If they did not have the "right" emotional balance, they risked the label of a "bad" mother.

\section{Discussion and Conclusions}

This article analyzes how and why women chose a childfree life. Our findings show two pathways to childfreedom: active and passive deciders. Some women "always knew" they did not want to be mothers; other women assumed they would have children, drifting until they took proactive steps to avoid motherhood. Still, other women were ambivalent or accepting of their childfree life. Our evidence suggests race, age, and relationship status shaped, at least in part, how women came to the decision to be childfree. Active deciders were mostly white; in fact, all certain women were white. Women of color drifted, then were active or accepted their childfree life. Ambivalent women were still in their childbearing years as were most active deciders; accepting women were all older than 40. All accepting women and those who drifted, then were active were single. However, our analysis of why women chose to remain childfree did not reveal patterns by their characteristics. Instead, the women similarly articulated their understandings of what motherhood would mean for their lives, valuing their childfree lifestyle, framing motherhood as a sacrifice, and viewing motherhood as a risk if they did not live up to societal expectations of a "good" mother.

We expected the decision to be childfree made in early adulthood might be different from a decision made toward the end of women's childbearing years (DeLyser, 2011; Gillespie, 1999; Ireland, 1993; Kelly, 2009; McAllister \& Clarke, 1998). We suggest three reasons for how age shaped the women's pathways. First, the focus on "just how life turned out" by women older than 40 may reflect how the meaning and interpretation individual's give to previous experiences can change over time, suggesting fluidity in how women frame their choice of a childfree life. Second, attitudes toward motherhood are shifting, so younger women may be more comfortable voicing their decision to be childfree. Thus, the women's framing of their childfree life as "how it turned out" masks structural constraints that shaped older women's decision to be childfree. Third, 
ambivalent women were firm with their intent to remain childfree, but given they were still of childbearing age acknowledged the possibility their circumstances could change. That later in their life these women may also retrospectively frame their childfree life as "how it turned out" is a distinct possibility. In fact, related to age was the women's relationship status: All women beyond childbearing were single. Most followed a passive pathway, highlighting constraints that led to their childfree choice; even active deciders recognized life circumstances played a major role in their decision not to mother.

We also expected there would be racial differences. All women of color either accepted their childfree life or had drifted, initially thinking they would be mothers, but then actively maintained childfreedom. We suggest that white women occupy a privileged position in society and the choice to be childfree may reflect that privilege. It may also reflect the expectation of white women to prioritize motherhood over any other identity like a career. In contrast, women of color have viewed motherhood and work as cohesive parts of women's identity (Hill Collins 1997; Lisle 1999; Nakano Glenn et al., 1994). Women of color may feel more social pressure or have greater access to familial caregiving arrangements (Clark 2012). All women of color were also single, avoiding motherhood based on a desire to share parenting with an intimate partner (Gerson 1985; Mezey 2008). This raises questions on the perceived (or real) eligibility of men, or men's comfort with women who choose not to mother or prioritize their career over family. For instance, Faye reflected on her dating life and thought her childfree lifestyle and focus on career intimidated black men. Conversely, white women were either sure they never wanted children or simply did not feel a strong draw toward motherhood. Acceptance of childfreedom reflected constraints women experienced, rather than choices. However, future research needs to tease out the relationship between race and how and why women chose to be childfree.

When women discussed the reasons for choosing to be childfree, they overwhelmingly focused on the benefits of their freedom and autonomy. Confirming other research, we found that childfree women interpreted motherhood as a "barrier to self-fulfillment, personal freedom, and marital happiness" (Callan, 1986, p. 180). In this study, women desired a "get up and go" lifestyle so they could travel, "hang" with family and friends, and learn new things. They cited obtaining a higher education, focusing on careers, and retaining other adult freedoms (Bartlett, 1994; Gillespie, 1999, 2000; Ireland, 1993; Kelly, 2009; Lisle, 1999; McAllister \& Clarke, 1998; McEvoy et al., 1984; Tomczak, 2012). When women compared the benefits of a childfree life to socially prescribed benefits, they chose not to mother (Morell, 2000).

The women's framing of the costs associated with motherhood focused on the many different ways their lives would change permanently. They understood motherhood as a lifelong commitment, some recognizing they still relied on their parents. Women interpreted children as disruptive and motherhood as sacrifice. Women believed they would have to abandon their career aspirations if they were mothers (Bartlett, 1994; Gerson, 1985; Gillespie, 1999, 2003; Ireland, 1993; McAllister \& Clarke, 1998; Park, 2005). Their reflections on work-family conflict are well supported in the literature. Women increasingly enter the paid labor 
market and stay after having children, but they experience a wage penalty for motherhood (Bartlett, 1994; Budig \& England, 2001; Correll, Benard, \& Paik, 2007). The women's financial concerns were also accurate. According to the USDA's report on Expenditures on Children by Families (Lino, 2011), the cost to raise a child is nearly $\$ 400,000$ from birth through age 18 (for households earning over $\$ 100,000)$, not including college education or health insurance after 18 years of age.

The benefits of childfreedom and the costs of motherhood were related to constraints that the women perceived mothers had to navigate. Women expressed concern they would not be "good" mothers because they did not have that "mother instinct" (Park, 2005). Or women did not believe they could find balance among caring, hovering, and patience. The emotional risks motherhood entailed reaffirmed societal expectations of women as nurturing. The women's choice to remain childfree was not a rejection of children overall, but to defy motherhood in their everyday lives. Many enjoyed children but appreciated the "quietness" of their life. They admitted part of their choice was driven by selfishness, believing their identity would shift from "an interesting friend who has all these hobbies" to "mommy," revealing societal expectations of motherhood as women's primary identity and exposing them to the risk of living up to all that mothering required.

The increasing number of childfree women warrants further investigation. Based on our findings, we suggest a few avenues for future research. First, scholars should expand beyond white, heterosexual, middle-class women who are college-educated to capture how race, ethnicity, sexuality, and class shape women's choices and perceptions of motherhood. Childfree research has largely ignored both women of color and lesbian women. Our study was limited based on education (all but three were college-educated) and sexuality (all women identified as heterosexual), but there was some diversity by race, allowing us to identify preliminary patterns for future investigation. Second, there has also been a dearth of research on childfree men. By focusing exclusively on women, we ignore men's choices and perceptions of childfreedom and the dyadic practices many couples experience while making such an important decision. Last, examining women's decision-making over time could yield some interesting patterns in how age and life course status shape women's decision-making processes.

\section{References}

Abma, J. C., \& Martinez, G. (2006). Childlessness among older women in the United States: Trends and profiles. Journal of Marriage and the Family, 68, 1045-1056.

Arendell, T. (2000). Conceiving and investigating motherhood: The decade's scholarship. Journal of Marriage and the Family, 62, 1192-1207.

Avellar, S., \& Smock, P. J. (2003). Has the price of motherhood declined over time? A cross-cohort comparison of the motherhood wage penalty. Journal of Marriage and the Family, 65, 597-607.

Bartlett, J. (1994). Will You Be Mother? Women Who Choose to Say No. New York, NY: New York University Press. 
Blackstone, A., \& Stewart, M. D. (2012). Choosing to be childfree: Research on the decision not to parent. Sociology Compass, 6/9, 718-727.

Brown, J. A., \& Ferree, M. M. (2005). Close your eyes and think of England: Pronatalism in the British print media. Gender \& Society, 19, 5-24.

Budig, M., \& England, P. (2001). The wage penalty for motherhood. American Sociological Review, 66, 204-225.

Burd, I. (2012). Later age pregnancy. Retrieved from University of Maryland Medical Center website:

http://umm.edu/health/medical/pregnancy/specialcare-pregnancies/laterage-pregnancy

Callan, V. J. (1986). Single women, voluntary childlessness and perceptions about life and marriage. Journal of Biosocial Science, 18, 479-487.

Clark, A. (2012). A phenomenology of the meaning of motherhood for African American and Hispanic women who do not have children in the United States. (Doctoral dissertation). Department of Sociology, University of Nebraska.

Collins, P. H. (1997). The meaning of motherhood in Black culture and Black mother/daughter relationships. In M. Baca Zinn, M. A. Messner, \& P. Hondagneu-Sotelo (Eds.), Through the prism of difference: Readings on sex and gender. Boston: Allyn \& Bacon.

Correll, S. J., Benard, S., \& Paik, I. (2007). Getting a job: Is there a motherhood penalty? American Journal of Sociology, 112, 1297-1338.

DeLyser, G. (2011). At midlife, intentionally childfree women and their experiences of regret. Clinical Social Work Journal, 40, 66-74.

Emerson, R. M., Fretz, R. I., \& Shaw, L. L. (1995). Writing ethnographic fieldnotes. Chicago, IL: University of Chicago Press.

Feldman, H. (1981). A comparison of intentional parents and intentionally childless couples. Journal of Marriage and the Family, 43, 593-600.

Gerson, K. (1985). Hard choices: How women decide about work, career, and motherhood. Berkeley: University of California Press.

Gillespie, R. (1999). Voluntary childlessness in the United Kingdom. Reproductive Health Matters, 7, 43-53.

Gillespie, R. (2000). When no means no: Disbelief, disregard and deviance as discourses of voluntary childlessness. Women's Studies International Forum, 23, 223-234.

Gillespie, R. (2003). Childfree and feminine: Understanding the gender identity of voluntarily childless women. Gender \& Society, 17, 122-136.

Heaton, T. B., Cardell, K. J., \& Holland, K. (1999). Persistence and change in decisions to remain childless. Journal of Marriage and the Family, 61, 531-539.

Ireland, M. (1993). Reconceiving women: Separating motherhood from female identity. New York, NY: Guilford Press.

Jacobs, J. A. \& Gerson, K. (2004). The time divide: Work, family, and gender inequality. Cambridge, MA: Harvard University Press.

Kelly, M. (2009). Women's voluntary childlessness: A radical rejection of motherhood? Women's Studies Quarterly, 37, 157-172. 
Koropeckyj-Cox, T., Romano, V., \& Moras, A. (2007). Through the lenses of gender, race, and class: Students' perceptions of childless/childfree individuals and couples. Sex Roles, 56, 415-428.

Letherby, G. (2002). Childless and bereft? Stereotypes and realities in relation to 'voluntary' and 'involuntary' childlessness and womanhood. Sociological Inquiry, 72, 7-20.

Lisle, L. (1999). Without child: Challenging the stigma of childlessness. New York, NY: Routledge.

Lino, M. (2011). Expenditures on children by families, 2010. (Miscellaneous Publication No. 1528-2010). U.S. Department of Agriculture, Center for Nutrition Policy and Promotion.

Majumdar, D. (2004). Choosing childlessness: Intentions of voluntary childlessness in the United States. Michigan Sociological Review, 18, 108-135.

McAllister, F. \& Clarke, L. (1998). Choosing childlessness. Family Policy Studies Centre and Joseph Rowntree Foundation. London.

McEvoy, B., DeVellis, B., Strudler, W., \& Acker, D. (1984). Childfree by choice: Attitudes and adjustment of sterilized women. Population and Environment, 7, 152-162.

McQuillan, J., Greil, A., Shreffler, K., \& Tichenor, V. (2008). The importance of motherhood among women in the contemporary United States. Gender \& Society, 22, 477-496.

Mezey, N. (2008). New choices, new families: How lesbians decide about motherhood. Baltimore, MD: The Johns Hopkins University Press.

Morell, C. M. (1994). Unwomanly conduct: The challenges of voluntary childlessness. New York, NY: Routledge.

Morell, C.M. (2000). Saying no: Women's experiences with reproductive refusal. Feminism and Psychology, 10, 313-322.

Nakano Glenn, E., Chang, G., \& Forcey, L. R. (Eds.). (1994). Mothering: Ideology, experience, and agency. New York, NY: Routledge.

Park, K. (2002). Stigma management among the voluntarily childless. Sociological Perspectives 45(1), 21-45.

Park, K. (2005). Choosing childlessness: Weber's typology of action and motives of the voluntarily childless. Sociological Inquiry 75(3), 372-402.

Parker West, L. (2002). Soccer moms, welfare queens, and super moms: Myths of motherhood in state media coverage of child care. Working paper. Emory University, Atlanta, GA.

Ridgeway, C. L., \& Correll, S. (2004). Motherhood as status characteristic. Journal of Social Issues, 60, 683-700.

Russo, N. F. (1976). The motherhood mandate. Journal of Social Issues, 32, 143153.

Somers, M. D. (1993). A comparison of voluntarily childfree adults and parents. Journal of Marriage and the Family, 55, 643-650.

Tomczak, L. (2012). Childfree or voluntarily childless? The lived experience of women choosing non-motherhood (Master's thesis). Department of Sociology, Northern Arizona University. 
U.S. Department of the Census. (2000). America's families and living arrangements.

U.S. Bureau of Labor Statistics. (2013). Women in the labor force: A databook. Retrieved from http://www.bls.gov/cps/wlf-databook-2013.pdf

U.S. Department of Commerce. (2011). Women in America: Indicators of social and economic well-being. White House Council on Women and Girls. Retrieved from

http://www.whitehouse.gov/sites/default/files/rss_viewer/Women_in_Ame rica.pdf?loc=interstitialskip

Veevers, J. E. (1973). Voluntary childlessness: A neglected area of family study. The Family Coordinator, 22(2), 199-205.

Vesper, P. (2008). No to children, yes to childfreedom: Pronatalism and the perspectives and experiences of childfree women (Master's thesis). Department of Liberal Studies, Rutgers University, Camden, NJ.

Vinson, C., Mollen, D., \& Smith, N. (2010). Perceptions of childfree women: The role of perceivers' and targets' ethnicity. Journal of Community and Applied Social Psychology, 20, 426-432. 


\section{Appendix \\ Interview Guide}

\section{Decision-Making}

1. Have you made a choice not to have children?

a. Can you tell me how you came to this decision?

2. Can you tell me about the reasons for your decision to not have children?

3. When did you know you weren't going to have children?

a. Can you talk about experiences that stand out in your mind that contributed to your decision not to have children?

4. When you think of pregnancy and childbirth, what comes to mind?

5. Have you talked to your partner (or past partners) about children?

a. In your current or previous relationships, in what phase of the relationship do you generally have this discussion?

\section{Responses by Families, Friends, and Others}

6. Can you tell me how your family members have commented on your decision not to have children?

a. When you go to holiday or family events, can you describe for me what the conversations are like, with regards to children?

7. When you and your friends talk about children, what are those conversations like? What kinds of responses have your friends made about your decision to not have children?

8.

\section{Life as a Childfree Woman}

9. Can you tell me how you think your life is different than your friends or family members that have children?

10. Have there been moments when you second-guess the decision, or moments when you thought you made the right decision?

11. For women beyond childbearing years: Have your experiences as a woman without children changed over time?

12. For women in childbearing years: Do you think you'll ever change your mind?

a. Under what circumstances?

13. Do you have friends or colleagues that have also made the decision to not have children? Can you describe for me what you talk about when the issue of children comes up?

14. Is there a label you would give yourself, with regards to not having children?

a. Would you consider yourself "childfree," "childless," or something else?

b. When you think of the term "childfree," what does it mean to you? What about "childless"?

15. Is there anything we didn't cover that you'd like to talk about?

16. Do you know any other women who would be interested in participating in this study? 